\title{
研究資料
}

\section{I $\mathrm{C} P$ 発 光 分 析}

久保田 正 明*

\section{1.はじめに}

誘導結合型プラズマ(Inductively Coupled Plasma, 以 下 ICP と略す) とは，高周波磁界により無電極放電を生 じさせて得られるプラズマをいう。このプラズマを光 源とする発光分光分析法の開発は, 1960 年代中頃に

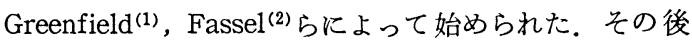
装置, 応用の両面で急速に発展し, 今や原子吸光分析法 と並ぶ主要な分光分析法として各分野に普及しつつあ る.

通常使用される ICP は周波数数〜数十 $\mathrm{MHz}$, 高周波 電力 $1 \sim 2 \mathrm{~kW}$ の常圧アルゴンプラズマである。分析法 としての特長は，(1)多くの元素に対し $\mathrm{ppm} \sim \mathrm{ppb}$ の検 出感度を示す，(2)多元素を迅速に同時定量できる， (3)繰返し精度および長時間安定性にすぐれている， (4) 検量線の直線域が広い ( $3 \sim 5$ 桁)，(5) 共存物質の影 響が少ない，などがあげられる。

本稿では装置や原理の基礎的事項には簡単にふれるに とどめ，主として最近の研究と鉄鋼分析への適用上の問 題点について述べる，基礎就よび応用に関する詳細は，

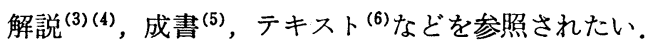

\section{2. 装置と動作原理}

装置構成図を図 1 亿示した。高周波発生装置には, 周 波数 $27 \mathrm{MHz}$ ，水晶制御発振方式のものが最も多く使用 されている. 3 重構造の石英管の最も外側の管にプラズ マガス(冷却ガス)として $1.7 \sim 3.3 \times 10^{-4} \mathrm{~m}^{3} / \mathrm{s}(10 \sim 20 \mathrm{~L} /$ $\mathrm{min})$ のアルゴンを, 2 番目の管に $1.7 \sim 3.3 \times 10^{-5} \mathrm{~m}^{3} / \mathrm{s}$ (1 2 L/min)のアルゴンを補助ガス (プラズマ保持用ガ ス) として流す。試料溶液は $0.8 \sim 2.5 \times 10^{-5} \mathrm{~m}^{3} / \mathrm{s}(0.5 \sim$ $1.5 \mathrm{~L} / \mathrm{min})$ のアルゴンをキャリヤーガスとしてネブライ ザーにより噴霧され，中心の細い石英管を通ってプラズ マ中導入される、プラズマを通過する間に溶媒は気化

* 工業技術院化学技術研究所主任研究官

ICP Emission Spectrochemical Analysis; Masaaki Kubota (National Chemical Lab. for Industry, Ibaraki)

1981 年 10 月 28 日受理
し試料物質が解離して励起発生する。プラズマからの光 は集光系を通して分光器に導き，各元素のスペクトル線 波長位置にセットされた光電子増倍管を用いてスペクト
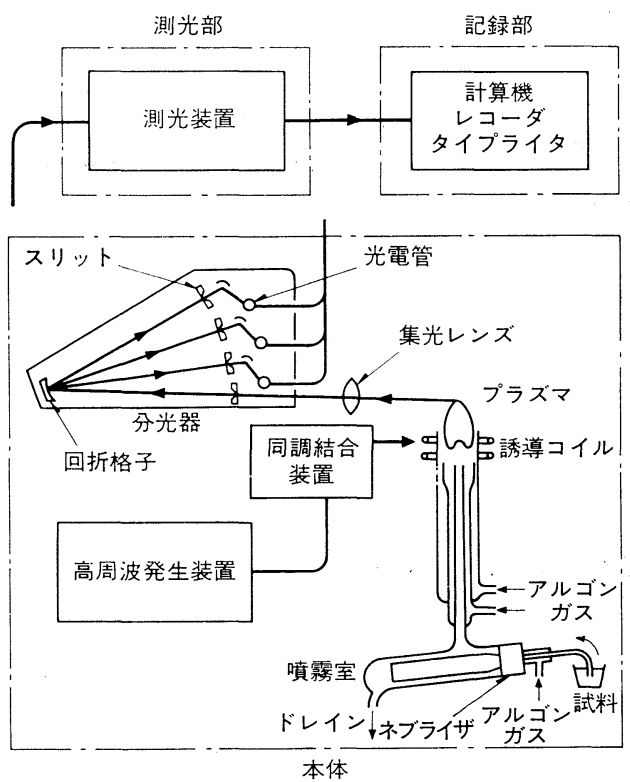

図 1 ICP 発光分析装置の構成図。

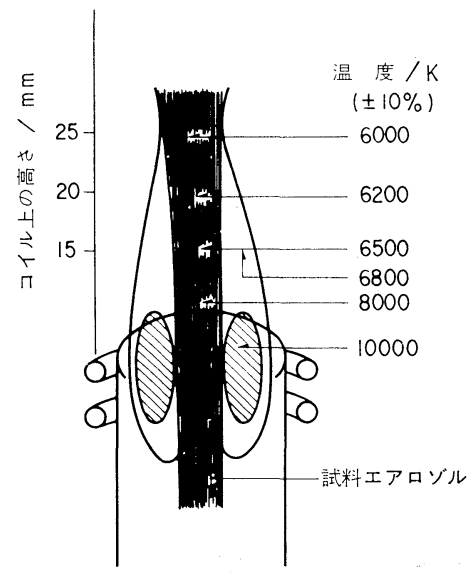

図2 プラズマの形状と温度分布 ${ }^{(6)}$. 
ル線強度を測定する. 図1では分光器としてポリクロメ 一タ(多チャンネル型)を示したが，この浪かに波長走査 型のモノクロメータ(単チャンネル型) るある。

図 2 にプラズマの形状と温度(励起温度)を示した。高 周波電流の電流密度は表皮効果のためにプラズマの外周 部ほど大きくなる，水分を含むキャリヤーガスが電流密 度の小さいプラズマ中心部を通過すると，その部分の温 度が一層低下してドーナツ状のプラズマが形成される。 図中の斜線で示した高温部は連続スペクトルが強く現わ れる部分であり分析には利用できない. 分析用の観測位 置はコイル上 $15 \mathrm{~mm}$ の附近である。

\section{3. 装置関係の研究と問題点}

\section{(1) 試料導入系}

代表的な噴霧器として、コンセントリック型あるいは クロスフロー型のニュマティックネブライザー, 超音波 ネブライザー拉よび Babinton 型ネブライザーがある. 通常の市販装置ではニュマティックネブライザーを噴霧 室に結合して試料導入系としている，構造が単純で使い やすいという利点を持つ反面, 霧化効率が低い(通常数 $\%$ 以下)，塩濃度の高い溶液を噴霧すると目づまりを生 じやすい，試料粘度によって噴霧量が変化する，などの 難点がある，目づまりを避ける 1 つの方策としては， 試料を断続的に導入する Injection method がある. Broekaert ら ${ }^{(7)}$ の方法は, $500 \mathrm{~mm}^{3}(500 \mu \mathrm{L})$ 量の溶液をマ イクロピペットで試料カップにとりペリスタルポンプ でコンセントリックネブライザーに送入する. 塩濃度 20 $\mathrm{kg} / \mathrm{m}^{3}(20 \mathrm{mg} / \mathrm{mL})$ までの溶液に適用できるが, 通常の連 続噴霧法に比べると検出感度は劣る。

超音波ネブライザーは微細な霧を効率よく発生させる ことができ，脱溶媒装置と組合わせて用いると極めて高 い感度を得ることができる ${ }^{(8)}$. しかしながら試料交換の 操作が煩雑なこと, 霧発生量の安定性に欠けるといら久 点は未だに十分解決されていない，

Babinton 型ネブライザーは，1977 年，Fry ら ${ }^{(9)}$ とよ り原子吸光用ネブライザーとして始めて分析に利用され た. 約 $\phi 0.6 \mathrm{~mm}$ のガス噴出用オリフィスをもった球状 または半球状のガラス表面に試料溶液を膜状に流し，才 リフィス部分を通過する溶液を高めの圧力の噴霧ガスで 霧化するものである。 その後, 溶液を流すV字溝がつけ られ，オリフィス径を小さくして $1.7 \times 10^{-5} \mathrm{~m}^{3} / \mathrm{s}(1 \mathrm{~L} /$ min) 程度のガス流量で噴霧できるように改良されて ICP 発光分析にる使用されるよらになった ${ }^{(10) \sim(12)}$. 溶液 の通過するキャピラリーをもたないので，塩濃度の高い 試料ばかりでなく微粒子を含有する溶液やスラリー状試 料を噴霧するのに適している。霧化効率の改善やメモリ 一効果の問題が検討課題であろう. 図 3 はキャリヤーガ

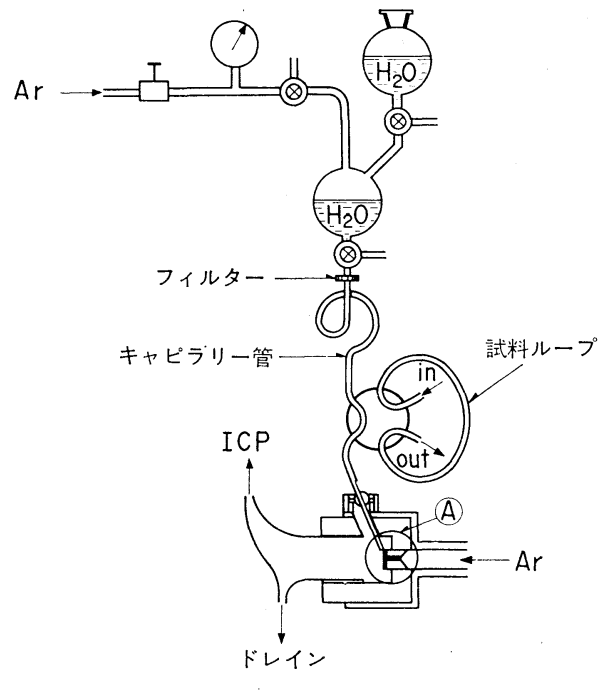

ネブライザー(A部)拡大図

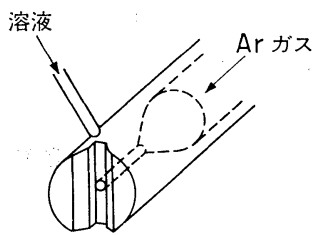

図 3 Babington 型ネブライザーを用いた試料導入 系 ${ }^{(13)}$.

ス流量 $1.7 \times 10^{-6} \mathrm{~m}^{3} / \mathrm{s}(0.1 \mathrm{~L} / \mathrm{min})$ で噴霧できるステン レス製の Babinton 型ネブライザー(オリフィス径 0.1 $\mathrm{mm})$ である. 試料の送入にはペリスタルポンプを用いる 代わりにアルゴンガスの圧力を利用している。

金属固体や粉体試料導入法の研究は, 試料分解の操作 を省くことができるという意味で興味ある課題であり， 多くの試みがなされている。最近の報告でもアーク放 電やレーザー光を用いて試料をエアロゾル化する方 法(14)(15)や，黒鉛炉を直接誘導コイル内に挿入する方 法(16)(17)などがある。しかしながら，これらの方法では 試料の物理的性質やマトリックスによる蒸発量への影響 が避けられない，したがって，溶液法に代わり得る可能 性は少なく，その用途子特殊な目的の場合に限られよ 5.

(2) ミニトーチ，水冷トーチなど

ICP の問題点の 1 つしてアルゴン消費量の大きい点 がしばしば指摘される，プラズマガス流量を減らすため トーチ管を小型化したり水冷する試みが行われ，アルゴ ンの代わりに窒素を用いる方法も検討されている。

Savage ら ${ }^{(18)}$ のミニトーチはトーチ管の大きさを従来 のトーチ管より $33 \%$ 縮小したもので, 電力 $1 \mathrm{~kW}$ 以下, プラズマガス流量は $1.3 \times 10^{-4} \mathrm{~m}^{3} / \mathrm{s}(8 \mathrm{~L} / \mathrm{min})$ で絧む. 検出感度は通常の ICP と差がないが,プラズマ温度がや 
や低く，解離平衡に関係した化学干涉に注意する必要が 西る(19). 水冷ト一チ関しては Kornblum ら ${ }^{(20)}$, 河口 ら (21)の報告がある。前者のトーチではプラズマガスを $1.5 \times 10^{-5} \mathrm{~m}^{3} / \mathrm{s}(0.9 \mathrm{~L} / \mathrm{min})$ 飞まで減らすことができる が,キャリヤーガスも $1.7 \times 10^{-6} \mathrm{~m}^{3} / \mathrm{s}(0.1 \mathrm{~L} / \mathrm{min})$ まで減 少させねばならず，検出限界は通常の ICP ょり 2 3 桁 高めになる。後者のト一チの場合プラズマガス流量は $6.7 \times 10^{-5} \mathrm{~m}^{3} / \mathrm{s}(4 \mathrm{~L} / \mathrm{min})$ で,キャリヤーガス流量は従来 型と変わらない，石英管の長さを延長してプラズマへの 空気の混入を防ぐことによりバックグラウンドを低下さ せており, 通常のICP と同じかやや低い検出限界が得ら れている。

窒素の利用法としては，プラズマガスにアルゴン一窒 素混合ガスあるいは窒素のみを用いる場合，扣よびプラ ズマガス,補助ガス,キャリヤーガスのすべてに窒素を用 いる場合とがある，窒素はバックグラウンドを低くする が, $\mathrm{N}_{2}, \mathrm{~N}_{2}{ }^{+}$などの帯スペクトルが 300〜450 nm 領域に 現われる。 また, アルゴンー窒素プラズマや窒素プラズ マでは, プラズマ維持にアルゴンプラズマより高い電力 を必要とする. Barnes ら ${ }^{(22)}$ は電力 $1.3 \mathrm{~kW}$ で動作でき る窒素プラズマを報告しているが，アルゴンプラズマに 比べてイオン線強度が弱く, CaII $393.3 \mathrm{~nm}$ を分析線 に用いた場合の $\mathrm{Ca}$ の検出限界はアルゴンプラズマより 800 倍も高くなっている。一方, Montaser ら ${ }^{(23)}$ のアル ゴン - 10\%窒素プラズマは, 16 元素についてアルゴンプ ラズマに匹敵する感度を示しているが，アルゴン消費量 節約といら面からはあまり意味がないといえる。

\section{(3) 分光測光系}

図 1 に示した多チャンネル型のシステムでは, 最大数 十元素を迅速に同時定量できるが，装置が高価であり， 波長設定されているスペクトル線しか使用できないとい う難点がある。これに対して波長走査型のモノクロメー タの場合には，分析所要時間が長くなるもの の,任意のスペクトル線を選択できる,近接線 やバックグラウンドが観測できる, 装置が比 較的安価(1000〜2000万円)などの利点があ る.この方式ではコンピュータを用いて走査 速度の制御やピーク強度の決定, 繰返し測定 などが行われて和り (24)(25)，市販装置におい てもマイクロコンピュータを内蔵した装置が 標準型になってきている。

光電子增倍管を用いない新しい測光系とし て,イメージ検出器を利用したシステムがあ る. 検出器として, イメージディセクター, SIT (Silicon Intensified Target Tube), フォ トダイオードアレイなどが使用されて括り， 特にフォトダイオードアレイに関しては Horlick ら ${ }^{(26)(27)}$ とよって多くの検討が行わ
れている.イメージ検出器による測光方式では, 従来の 写真測光法と同様, ある波長域に亘るスペクトル情報を 同時に観測することができる。しかしながら現在のとこ ろでは分解能や紫外領域での感度が十分でなく, プラズ マに打けるスペクトル線強度分布の測定などに利用され ているにすぎない、今後検出器の性能が改善されるにつ れて実用分析へも適用範围が広がるものと期待される。

\section{4. プラズマの特性}

\section{(1) プラズマパラメータと測定条件の最適化}

プラズマの発光特性は高周波電力, プラズマガス流量, 補助ガス流量, キャリヤーガス流量, 観測高さなどのプラ ズマパラメータによって定まる。測定条件を最適化する には SB 比(信号強度/バックグラウンド強度)あるいは $\mathrm{SN}$ 比(信号強度/ノイズ)が最大になるようこれらパラ メータの值を設定する，ところでプラズマパラメータ間 には相互に依存性があり，1つのパラメータだけ変化さ せても最適条件は決まらない. Ebdon ら (28), Terblanche ら ${ }^{(29)}$ は，条件設定に Simplex optimizationを適用する と, 短時間で SB 比最大の条件が求められることを示し た。この方法は, 複数のパラメータを变化させ, 四形上 で最小の $\mathrm{SB}$ 比を示す点を除く操作を $\mathrm{SB}$ 比が変わらな くなるまで繰り返し,条件を最適化する方法で,Ebdon ら は Mn について約 25 回の繰り返しで最適条件を決定し た。

なお，上記のプラズマパラメータの中でプラズマガス 流量と補助ガス流量は他のパラメータに比べてその影響 が小さいので，これらを一定に保って残りの 3 つのパラ メータで最適化しても実用上はほぼ問題がない。この場 合は図 4 に示すような 3 次元図形で表わした方がパラメ 一タ間の相互関係を把握しやすい，図中の BEC (Back-
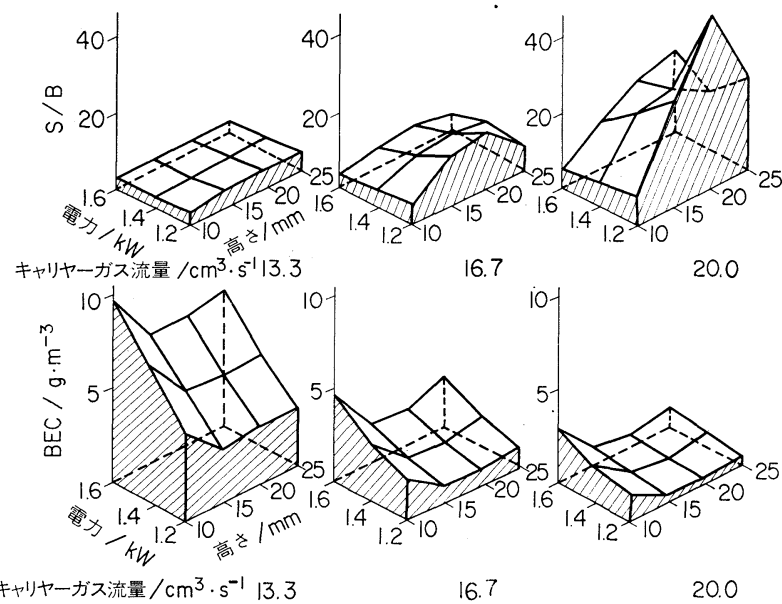

図 $4 \mathrm{Al}$ I $396.15 \mathrm{~nm}$ 線の S/B 比, BEC に対する高周波 電力, 観測高さ, キャリヤーガス流量の影響 ${ }^{(30)}$. 
ground Equivalent Concentration)は, ある元素の信号 強度がバックグラウンド強度と等しくなる時のその元素 の濃度であり, この值が小さいほど検出限界は低いこと になる。通常 BEC の 1/100 程度の濃度が検出限界に相 当する.

\section{(2) 温度と電子密度}

ICP の温度としては，コイル上 $15 \mathrm{~mm}$ 附近において, 気体温度 3000 4000 K (OH 回転温度), $5000 \sim 6000 \mathrm{~K}$ (ド ップラー幅より), 励起温度 $5500 \sim 7000 \mathrm{~K}$, 電子温度括 よびイオン化温度 $>7500 \mathrm{~K}$ ，の值が報告されている。 これら 4 種の温度間に見られる大きな差は, プラズマが 熱平衡状態にないことを示している. 図 5 は半径方向に おける $\mathrm{Ar}$ の励起温度と $\mathrm{OH}$ 回転温度分布の測定例であ る.キャリヤーガスを流すことにより, 中心軸近くで温 度の低下する様子が認められる。

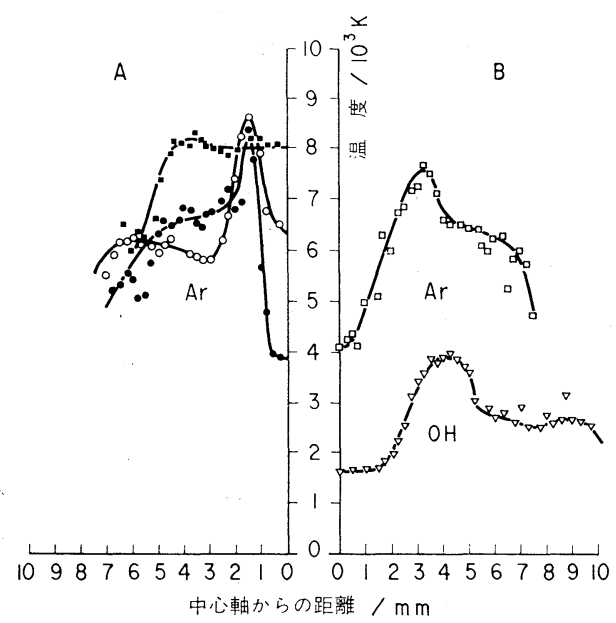

図 5 プラズマ半径方向の $\mathrm{Ar}$ 励起温度分布と $\mathrm{OH}$ 回転温度分布 ${ }^{(31)}$
A :
キャリヤーガス $0 \mathrm{~cm}^{3}$
0 $22.7 \mathrm{~cm}^{3} / \mathrm{s}$
コイル上 $12 \mathrm{~mm}$ $12 \mathrm{~mm}$
$3.75 \mathrm{~mm}$
$7.50 \mathrm{~mm}$

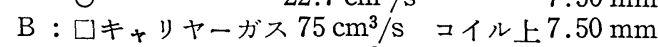 $\nabla$
$75 \mathrm{~cm}^{3} / \mathrm{s}$
$12 \mathrm{~mm}$

イオン化温度に対するキャリヤーガス流量や水分の影 響が検討されている ${ }^{(32)}$. また, プラズマの空間分布に関 する研究は多く, 最近では軸方向強度分布に対するマト リックス成分の影響 ${ }^{(33)}$, 励起温度と $\mathrm{OH}$ 回転温度の軸 方向分布 ${ }^{(34)}$, 半径方向の温度拈よびガス流速分布に関 する計算値と実測値の比較 ${ }^{(35)}$ などの報告がある。

電子密度はシュタルク広がりあるいは連続スペクトル 強度から計算することができる。 $\mathrm{H}_{\beta}$ 線のシュタルク広 がりから求めた結果によると $10^{21} \sim 10^{22} \mathrm{~m}^{-3}\left(10^{15} \sim 10^{16}\right.$ $\left.\mathrm{cm}^{-3}\right)$ である(31)(32). この值は直流アークプラズマより 約 1 桁大きく，スパーク放電の電子密度に近い，電子密 度はSaha の式を用いてイオン線・中性線の強度比から
求めることもできるが，イオン線強度が平衡值より高い ため得られる密度は低めとなる.

\section{(3) 励起機構}

ICP ではアルカリ元素の存在によるスペクトル線強度 への影響(イオン化干渉)が小さく, また, 直流アークプ ラズマに比較して原子線に対するイオン線の強度比が大 きい。この現象を説明するためにペニングイオン化機構 に基づく考え方が提案されている，すなわち，原子Xの イオン化エネルギーが準安定アルゴン原子 $\mathrm{Ar}^{\mathrm{m}}$ の励 起エネルギー $\left(18.5 \times 10^{-19} \mathrm{~J}(11.55 \mathrm{eV}), 18.8 \times 10^{-19} \mathrm{~J}\right.$ $(11.72 \mathrm{eV}))$ より大きい時, ペニング効果によって

$$
\mathrm{Ar}^{\mathrm{m}}+\mathrm{X} \rightarrow \mathrm{Ar}+\mathrm{X}^{+}+e
$$

の反応を生じ，Xはイオン化される．この場合 $\mathrm{Ar}^{\mathrm{m}}$ は 他の原子をイオン化する ionizer として働くが，それ自 身は

$$
\mathrm{Ar}^{\mathrm{m}}+e \rightarrow \mathrm{Ar}^{+}+2 e
$$

なる反応によりイオン化される成分 ionizant となる. Ar のイオン化電位と $\mathrm{Ar}^{\mathrm{m}}$ の励起準位との差は $6.7 \times$ $10^{-19} \mathrm{~J}(4.21 \mathrm{eV})$ なので, 低イオン化電位物質 $\mathrm{Ar}^{\mathrm{m}}$ がプ ラズマ中に多量存在して緩衝剤として作用寸るものと考 える(36). この考方は，イオン状態の overpopulation や高い電子密度を無理なく説明できるが, $\mathrm{Ar}^{\mathrm{m}}$ の密度 $\left(10^{20} \mathrm{~m}^{-3}\right.$ と推定されているがこの值は大きすぎる可能 性がある) や寿命などについての実証が必要である。電 子衝撃が励起とイオン化を支配する主要因とする推 論 ${ }^{(32)}$ もり, 一方, $\mathrm{Ar}^{\mathrm{m}}$ の密度分布の測定 ${ }^{(37)}$ も行われ ているので, 今後ペニングイオン化説の妥当性をめぐっ て議論が盛んになるものと思われる。

\section{5. 鉄鋼分析への適用と問題点}

\section{（1）感度と精度}

ICP 分析法の広い適用分野の中でも鉄鋼分析は最も普 及の著しい分野である。製鉄所に拈ける湿式化学分析の 作業能率は，カントバック分析や螢光 X線分析に比べて 極めて悪く, 従来より分析作業の省力化と迅速化が求め られてきたＩCP 分析法はこの要求に十分こたえ得る方 法であったといえる. ICP 分析法の特長の中でも, 多元 素同時定量性ならびに $\mathrm{Zr}, \mathrm{V}, \mathrm{W}$ などの耐火性元素と希 土類元素に対する高感度性は，原子吸光分析法にない利 点であり，省力化と迅速化につながる利点として鉄鋼分 析では特に重要な意義を持っている.

表 1 に $\mathrm{Al}$, Ce など 12 元素について Fe が共存する場 合としない場合とで検出限界を比較した． Feが共存す ると検出限界はわずかながら高めになる。なお，水溶液 での検出限界としてはこの表の值より 1 桁低い值も報告 されているが，各元素ごとに測定条件を最適化し，試料 導入に超音波ネブライザーを用いている場合が多いの 
表 1 水溶液 ( $\mathrm{Fe}$ 共存せず) および $0.5 \% \mathrm{Fe}$ 溶液で の検出限界比較 ${ }^{(38)}$.

\begin{tabular}{|c|c|c|c|c|c|}
\hline \multirow{3}{*}{ 元素 } & \multirow{3}{*}{$\begin{array}{l}\text { 波長 } \\
(\mathrm{nm})\end{array}$} & \multicolumn{3}{|c|}{ 検 出 限 界 } & \multirow{3}{*}{$\begin{array}{c}\text { 定量下限* } \\
\text { (in Fe, } \\
\text { 質量\%) }\end{array}$} \\
\hline & & \multirow{2}{*}{$\begin{array}{c}\mathrm{H}_{2} \mathrm{O} \text { 溶液 } \\
\left(\mathrm{g} / \mathrm{m}^{3}\right)\end{array}$} & \multicolumn{2}{|c|}{$0.5 \% \mathrm{Fe}$ 溶液 } & \\
\hline & & & $\left(\mathrm{g} / \mathrm{m}^{3}\right)$ & （質量\%) & \\
\hline $\mathrm{A} 1$ & 396.1 & 0.002 & 0.004 & 0.00008 & 0.0004 \\
\hline $\mathrm{Ce}$ & 456.2 & 0.007 & 0.013 & 0.0003 & 0.0015 \\
\hline $\mathrm{Cr}$ & 357.8 & 0.001 & 0.002 & 0.00004 & 0.0002 \\
\hline $\mathrm{Cu}$ & 324.7 & 0.001 & 0.0003 & 0.000006 & 0.00003 \\
\hline $\mathrm{La}$ & 398.8 & 0.003 & 0.003 & 0.00007 & 0.0004 \\
\hline $\mathrm{Mn}$ & 403.0 & 0.003 & 0.003 & 0.00007 & 0.0004 \\
\hline $\mathrm{Ni}$ & 351.5 & 0.06 & 0.07 & 0.001 & 0.005 \\
\hline $\mathrm{Nb}$ & 405.8 & 0.01 & 0.02 & 0.0004 & 0.002 \\
\hline $\mathrm{Pb}$ & 405.7 & 0.01 & 0.01 & 0.0002 & 0.001 \\
\hline $\operatorname{Pr}$ & 417.9 & 0.008 & 0.01 & 0.0002 & 0.001 \\
\hline W & 400.8 & 0.002 & 0.003 & 0.00006 & 0.0003 \\
\hline $\mathrm{Zr}$ & 349.6 & 0.02 & 0.02 & 0.0005 & 0.002 \\
\hline
\end{tabular}

$* 0.5 \% \mathrm{Fe}$ 溶液での検出限界 $\times 5$

で，実用上は表 1 の数值を参考にした方がよい、鉄鋼試 料の ICP 分析で感度が不足するのは, $\mathrm{As}, \mathrm{Bi}, \mathrm{Sb}, \mathrm{Se}, \mathrm{Sn}$, Zn などの微量不純物元素である。これらの元素の多く は原子吸光法に比較して感度が劣るので，単元素分析で あればあえて ICP を利用する必要はない，As，Sn に関 しては，真空紫外領域のスペクトル (As $189.04 \mathrm{~nm}, \mathrm{Sn}$ $189.99 \mathrm{~nm})$ を使用して感度の向上をはかる試みもなさ れている( ${ }^{(39)}$. 真空紫外部のスペクトルとしては,これら の元素以外にも $\mathrm{P}, \mathrm{B}, \mathrm{Hg}, \mathrm{S}, \mathrm{I}, \mathrm{Br}$ について利用が検討さ れている ${ }^{(40)}$. 特に $\mathrm{P}, \mathrm{B}, \mathrm{S}$ は鉄鋼分析に関係する元素と して興味深い.

$\mathrm{As}, \mathrm{Bi}, \mathrm{Ge}, \mathrm{Pb}, \mathrm{Sb}, \mathrm{Se}, \mathrm{Sn}, \mathrm{Te}$ の分析には試料導入に水 素化物生成反応を利用する方法もある。この方法は水素 化ホウ素ナトリウムなどの還元剤を用いて水素化物を生 成させ，溶液中から気体として分離させるもので，原子 吸光分析法ではすでに一般的方法となっている. ICP 分 析への適用にあたって, 酸濃度, $\mathrm{NaBH}_{4}$ 濃度, プラズ

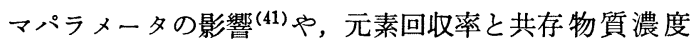
との関係 ${ }^{(42)}$ が詳細に検討されており，低合金鋼やアル ミニウム中の Sn の定量を行った報告(43) もある. 表 2 に
見るようにニュマティックネブライザーによる通常の 試料導入の場合に比較して 1 桁以上検出限界が低くなっ ており，原子吸光法の感度にほぼ匹敵している。なお， 検量線の直線域が広いといら点で原子吸光法より有利で ある.

分析精度は短時間での繰り返し精度によって表わされ る.この值は検出限界附近では通常数十\%に達するが, 検出限界の 10 倍の濃度の場合 3〜 5\% となり，100 倍の 濃度では $0.5 〜 1 \%$ となる. 鉄鋼関係の分析室では溶液 試料のセットからデータの出力まで完全自動化されたシ ステムを連続運転する場合が多く, 短時間精度のほかに 長時間の安定性が併せて重要になる。長時間安定度は, 主としてネブライザーの噴霧状態や高周波電力, ガス流 量などの経時変化によって影響を受ける。この影響は内 標準法を用いることにより減少させ得るが，分光測定系 に起因する信号強度の変動は補正されずに残る。したが って，一定時間ごとに標準化を行わなければならない. 高濃度溶液を噴霧した場合にも, ネブライザーの噴霧量 の変化のほかにメモリ一効果の恐れもあり, 標準溶液や ブランク溶液による検量線のチェックが必要である。

\section{（2）共存物質の影響}

共存物質の影響いわゆる干渉現象を要因別に分類する と次のようになる。

(a) 試料導入過程に起因するもの一一溶液の粘度, 表 面張力などの変化による噴霧量や霧の粒径, 粒度分布の 変化

(b) プラズマ中での現象に起因するもの一一化学的要 因として難解離性化合物の生成, 物理的要因としてプラ ズマ温度, 電子密度の変化によるイオン化平衡や制動放 射・再結合放射 (バックグラウンド発光)の変化

（c）分光測光過程に起因するもの一一妨害線の影響, 迷光, バックグラウンドの変化

試料分解酸による分析線強度への影響は(a), (b) の要 因によるが，特に(a)の影響が大きいと考えられる，A1 の発光強度に対する各種分解酸と濃度。影響を図 6 に示 した。この測定結果に見られるように，一般に酸濃度が

表 2 水素化物生成一ICP 発光法による検出限界と検量線直線域 $\left(\mathrm{mg} / \mathrm{m}^{3}\right)$.

\begin{tabular}{|c|c|c|c|c|c|c|}
\hline \multirow{2}{*}{ 元 素 } & \multicolumn{2}{|c|}{ Thompson $5^{(41)}$} & Wolnik $ら^{(44)}$ & 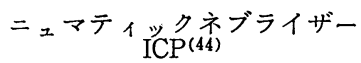 & \multicolumn{2}{|c|}{ 原子吸光法 ${ }^{(45)}$} \\
\hline & 検出限界 & $\begin{array}{l}\text { 検量線直線 } \\
\text { 域 } \text { 上限 }\end{array}$ & 検 出 限 界 & 検 出 限 界 & 検出限界 & $\begin{array}{l}\text { 検量線直線 } \\
\text { 域の上限 }\end{array}$ \\
\hline As & 0.8 & 800 & 3 & 20 & 0.8 & 20 \\
\hline $\mathrm{Bi}$ & 0.8 & 500 & 0.9 & 40 & 0.2 & 50 \\
\hline $\mathrm{Ge}$ & - & - & 20 & 200 & 500 & - \\
\hline $\mathrm{Se}$ & 0.8 & 800 & 0.5 & 20 & 1.8 & 200 \\
\hline $\mathrm{Sb}$ & 1.0 & 1500 & 0.7 & 20 & 0.5 & 50 \\
\hline $\mathrm{Te}$ & 1.0 & 250 & 0.7 & 20 & 1.5 & 200 \\
\hline
\end{tabular}




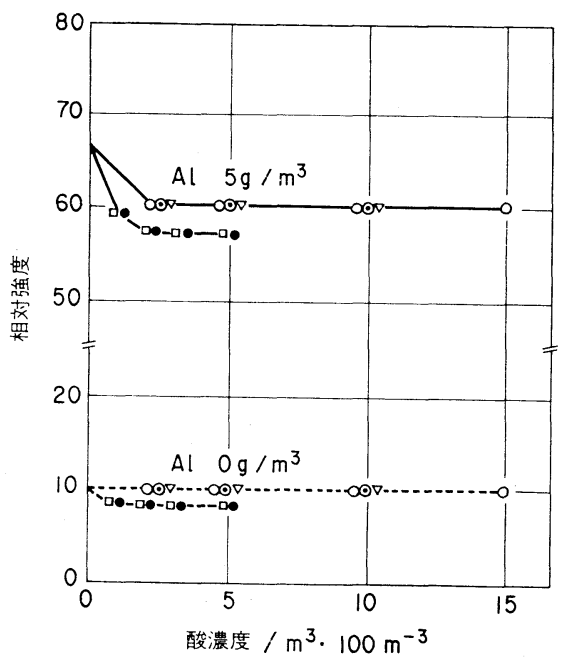

図6 Al I $396.15 \mathrm{~nm}$ 線およびバックグラウンド の強度に与兄る酸の影響(46). $\bigcirc \mathrm{HCl}, \odot \mathrm{HNO}_{3}, \nabla \mathrm{HClO}_{4}, \square \mathrm{H}_{2} \mathrm{SO}_{4}, \bullet \mathrm{H}_{3} \mathrm{PO}_{4}$

增大するにつれてスペクトル線強度は減少し，その傾向 は硫酸, 燐酸に打いて著しい。

抽出分離残さや鉄鉱石の処理には $\mathrm{Na}_{2} \mathrm{~S}_{2} \mathrm{O}_{7}, \mathrm{Na}_{2} \mathrm{CO}_{3}$, $\mathrm{Na}_{2} \mathrm{~B}_{4} \mathrm{O}_{7}$ などの融解剤を使用するため, 多量の $\mathrm{Na}$ がプ ラズマ中に導入される。すでに述べたように，イオン化 平衡への影響は比較的少ないが正確度への影響を完全に 無視できるわけはない，標準溶液のマトリックス成分濃 度を試料溶液のそれと等しくおくことが必要である。亦 ブライザーやトーチ管先端での目づまりを避けるために はできるだけ少量で済む融解剤を使用することが望まし い.

内標準法は主として (a)の影響を消去する方法として 有用であるが，スペクトル線の種別(原子線，イオン線） が分析線と内標準線との間で異なる場合や，励起電位に 大きな差がある場合には，プラズマの励起条件の変動に よる影響を受けやすくなり，分析值の正確度を低下させ る恐れがある.内標準元素としてYが最も好ましいとの 報告(47)(48)がある。

鉄鋼の主要成分元素である $\mathrm{Fe}, \mathrm{Cr}, \mathrm{Co}, \mathrm{V}, \mathrm{Mo}$ などの スペクトル線は，他の分析元素のスペクトル線に対して 妨害線となりやすい. 分光干涉による分析值への影響を 補正するために，鉄鋼中 Al, As, Co など 15 元素のスペ クトル線について，妨害元素ごとに補正係数が測定され ている ${ }^{(49)}$. 最近 ICP 分析用にスペクトル線相対強度や 近接線を示した波長表 ${ }^{(50)(51)}$ が出版された。実用分析上 利用価値は高い。

\section{（3）試料分解法}

ICP で同時定量できる元素数は装置上数十元素まで可 能であるが，現実には試料分解法によって制限を受け
る. 多元素同時定量用の試料分解法の研究は, 鉄鋼分析 に执いてとりわけ重要な課題である。また，分析操作の 中で試料処理の過程のみ自動化が遅れていて，ICP 分析 法の迅速性に適合しないという問題点もある。試料の科 量からデータ出力まで全行程の自動化が望まれる。

鋼試料の分解酸としては, $\mathrm{Cr}, \mathrm{Cu}$ など 7 元素の同時処 理に $\mathrm{HCl}+\mathrm{HNO}_{3}+\mathrm{HClO}_{4}{ }^{(52)}, \mathrm{Si}, \mathrm{Mn}$, 可溶性 $\mathrm{Al}$ など 12 元素に $\mathrm{HCl}(1+2)+\mathrm{H}_{2} \mathrm{O}_{2}(15 \%)^{(48)}, \mathrm{Al}, \mathrm{Ce}, \mathrm{Cr}$ など 12 元素に $\mathrm{HCl}(1+1)+\mathrm{HNO}_{3}{ }^{(38)}$, $\mathrm{Si}, \mathrm{Mn}, \mathrm{Ni}$ など 12 元素に 王水 (不溶解残さは $\mathrm{Na}_{2} \mathrm{CO}_{3}+\mathrm{H}_{3} \mathrm{PO}_{3}$ 処理) ${ }^{(53)}$ が使用され て频り, 抽出分離残さ中の $\mathrm{Nb}, \mathrm{Cr}, \mathrm{Fe}, \mathrm{Mo}, \mathrm{Mn}$ 飞対して は $\mathrm{Na}_{2} \mathrm{~S}_{2} \mathrm{O}_{7}$ で融解後 $20 \%$ 酒石酸溶液で抽出する方法 ${ }^{(54)}$ が報告されている。な拉，Si 関しては，Ti $\mathrm{Nb}$ ぞの不溶解残さを $\mathrm{HF}-\mathrm{HNO}_{3}$ 処理した場合のネブライザ 一, トーチ管侵食による $\mathrm{Si}$ のブランク值, $1 \%$ 以上の高 けい素試料に掓るけい酸の析出などに留意しなければ ならない。

スラグや鉄鈗石の分析に打いては融解剂の選択が最大 の検討課題である。融解操作の容易性, 融解時間, 不純 物濃度などを考慮するとともに，(2)で述べたように干 涉やネブライザーの目づまりに対する注意が必要であ る. ICP の利点を生かすためには, $\mathrm{SiO}_{2}$ を含めて数種の 酸化物を同時定量することが好ましく, 通常は $\mathrm{Na}_{2} \mathrm{CO}_{3}$ または $\mathrm{Na}_{2} \mathrm{CO}_{3}+\mathrm{K}_{2} \mathrm{CO}_{3}, \mathrm{Na}_{2} \mathrm{CO}_{3}+\mathrm{Na}_{2} \mathrm{~B}_{4} \mathrm{O}_{7}$ などが融解剂 として使われている。遠藤ら ${ }^{(55)}$ は鉄鉱石の分析のた め, 6 種類の融解剤を比較検討し, 作業性を考慮して $\mathrm{Na}_{2} \mathrm{CO}_{3}+\mathrm{Na}_{2} \mathrm{~B}_{4} \mathrm{O}_{7}$ の等量混合剂を使用している.

\section{6. おわりに}

ICP 発光分析について最近の研究と問題点を紹介し た。この方法は我が国では始め大学や国公立の研究機関 に導入されたが，ここ数年来鉄鋼業を始めとする民間企 業の分析現場での普及がめざましく，すでに百数十台を こえる装置が稼動しているといわれる，現場に拈けるユ 一ザーが増加した結果，より具体的な問題について詳細 な議論が要求される時期をむかえている，ICPは分析作 業の迅速化·省力化の点で確かに有用ではあるが，目的 や利用面を広げすぎると本来の利点を損ならことにもな る. 原子吸光分析法, 螢光 X線分析法などを併用しなが ら，ICP 分析法の特長を生かした使い方をすることが大 切と思われる。

\section{文献}

(1) S. Greenfield, I. L. Jones and C. T. Berry : Analyst, 89 (1964) , 713.

(2) R.H.Wendt and V.A.Fassel : Anal. Chem., 37 (1965), 920.

(3) V.A.Fassel and R.N.Kniseley: Anal. Chem, $46(1974), 1110 \mathrm{~A}$ and $1155 \mathrm{~A}$. 
（4）河口広司: 分光研究, 27 (1978), 387.

(5) 不破敬一郎, 原口紘串編 : 化学の領域増刊 127 号, ICP 発光分析, 南江堂, (1980).

（6）日本分光学会: 第 17 回夏期セミナーテキスト, ICP 発光分光分析, (1981).

(7) J.A.C.Broekaert and F.Leis : Anal. Chim. Acta, $109(1979), 73$.

(8) 例えば S.S.Berman, J.W.McLaren and S.N. Willie : Anal. Chem., 52(1980), 488.

(9) R.C.Fry and M.B.Denton: Anal. Chem., 49 (1977) , 1413.

(10) R.F.Suddendorf and K.W.Boyer : Anal.Chem., $50(1978), 1769$.

(11) J.F.Wolcott and C.B.Sobel : Appl.Spectrosc.,32 (1978), 591.

(12) Bo Thelin : Analyst, 106 (1981) , 54.

(13) P.A.M.Ripson and L.de Galan : Spectrochim. Acta, 36B (1981), 71.

(14) K.Ohls and D.Sommer : Z.Anal. Chem., 296 (1979), 241.

(15) M. Thompson, J.E. Goulter and F. Sieper : Analyst, 106 (1981), 32.

(16) E.D.Salin and G.Horlick : Anal. Chem., 51 (1979) , 2284.

(17) D.Sommer and K.Ohls : Z.Anal. Chem., 304 (1980), 97 .

(18) R.N.Savage and G.M.Hieftje : Anal.Chem., 51 (1979), 408.

(19) R.N.Savage and G.M.Hieftje : Anal.Chem., 52 (1980) , 1267

(20) G. R. Kornblum, W. V. der Waa and L.de Galan : Anal. Chem., 51 (1979), 2378.

(21) H.Kawaguchi, T.Ito, S.Rubi and A.Mizuike : Anal. Chem., 52 (1980), 2440.

(22) R.M.Barnes and G.A.Meyer : Anal. Chem., 52 (1980) , 1523.

(23) A.Montaser and J.Mortazavi : Anal.Chem., 52 (1980) , 255.

(24) T.Catterick and D.A.Hickman : Analyst, 104 (1979), 516.

(25) M.A.Floyd, V.A.Fassel, R.K.Winge, J.M. Katzenberger and A.P.D'Silva : Anal. Chem., $52(1980), 431$.

(26) K.R.Betty and G.Horlick : Appl. Spectrosc., 32 (1978), 31.

(27) E.D.Salin and G.Horlick : Anal. Chem., 52 (1980), 1578.

(28) L.Ebdon, M.R.Cave and D. J. Mowthorpe: Anal. Chim. Acta, 115(1980), 179.

(29) S.P.Terblanche, K.Visser and P.B.Zeeman : Spectrochim. Acta, 36B (1981), 293.

(30) 今井 覚: 文献 (6) p. 20 .
(31) G.R.Kornblum and L. de Galan : Spectrochim. Acta, 32B (1977), 71.

(32) J.F.Alder, R.M.Bombelka and G.F.Kirkbright: Spectrochim. Acta, 35B (1980), 163.

(33) H.Kawaguchi, T.Ito, K.Ota and A.Mizuike : Spectrochim. Acta, 35B (1980), 199.

(34) H.Kawaguchi, T.Ito and A.Mizuike : Spectrochim. Acta, 36B (1981), 615.

(35) R.M.Barnes and R.G.Schleicher : Spectrochim. Acta, 36B (1981), 81.

(36) P.W.J.M.Boumans and F.J.de Boer : Spectrochim. Acta, 32B(1977), 365.

(37) H.Uchida, K.Tanabe, Y.Nojiri, H.Haraguchi and K.Fuwa : Spectrochim. Acta, 36B (1981), 711 .

(38) C.C.Butler, R.N.Kniseley and V.A.Fassel : Anal. Chem., 47 (1975), 825.

(39) T.Hayakawa, F.Kikui and S.Ikeda : 9th ICAS/ XXII CSI Abstracts, (1981), 29.

(40) Y.Omori, T.Masuda, S.Asada and S.Imai : 9th ICAS/XXII CSI Abstracts, (1981), 31.

(41) M. Thompson, B. Pahlavanpour, S. J. Walton and G.F.Kirkbright : Analyst, 103 (1978), 568.

(42) M. Thompson, B. Pahlavanpour, S. J. Walton and G.F.Kirkbright : Analyst, 103 (1978), 705.

(43) D.Sommer, K.Ohlsand A.Koch : Z.Anal.Chem., $306(1981), 372$.

(44) K.A.Wolnik, F.L.Fricke, M.H.Hahn and J. A.Caruso : Anal. Chem., 53 (1981), 1030.

(45) K.C.Thompson and D.R.Thomerson : Analyst, 99 (1974), 595.

(46) 遠藤芳秀, 斎藤啓二, 中原悠紀 : 鉄と鋼, 64 (1978), 117 .

（47）遠藤芳秀, 坂尾則隆 : 日本鉄鋼協会第 101 回講演 大会講演要旨集 I, (1981), 383 .

(48) 柴田 勉: 交献 (6) p.43.

(49) A.F.Ward and L.F.Marciello: Anal.Chem., 51 (1979), 2264.

(50) M.L.Parsons, A.Forster and D.Anderson : An Atlas of Spectral Interferences in ICP Spectrometry, Plenum Press, New York, (1980).

(51) P.W.J.M.Boumans : Line Coincidence Tables for Inductively Coupled Plasma Atomic Emission Spectrometry, Vol.1 \& 2, Pergamon Press, Oxford, (1980).

(52) 遠藤芳秀, 坂尾則隆：A \& R, $17(1979), 105$.

(53) 田中勇, 田原貞夫, 大槻 孝, 佐藤公隆, 松本 龍太郎: 分析化学, $28(1979), 371$.

(54) F.Kurosawa, I.Tanaka, K. Sato and T.Otsuki: Spectrochim. Acta, 36B (1981), 727.

(55) 遠藤芳秀, 坂尾則隆：鉄之鋼, 66(1980), 1395 . 